\title{
SYNTHESIS OF HETEROCYCLIC PYRIDINE-BASED CHALCONES WITH DIMERIC STRUCTURE
}

\author{
Pui-Mun Lai ${ }^{1}$, Sie-Tiong $\mathrm{Ha}^{1, \otimes}$
}

https://doi.org/10.23939/chcht16.01.001

\begin{abstract}
Three new heterocyclic chalcones containing pyridine moiety were synthesized and their chemical structures were determined via $\mathrm{IR},{ }^{1} \mathrm{H} \mathrm{NMR}$ and ${ }^{13} \mathrm{C} \mathrm{NMR}$ spectroscopy. General name of these compounds are $\alpha, \omega-$ bis \{3-(pyridin-3-yl)-1-(phenyl-4-oxy)prop-2-en-1-one\}alkanes. The chalcones are dimers having a symmetrical structure and they can be differed by the alkyl spacer length $\left(\mathrm{C}_{n} \mathrm{H}_{2 n}\right.$, where $\mathrm{n}=8,10$ or 12 ). Differential scanning calorimetry (DSC) technique was employed to study their phase transition behaviors. DSC thermograms displayed direct isotropization and recrystallization during heating and cooling processes, respectively. The crystal phase turned into isotropic phase without exhibiting any mesophase. Influence of structure-liquid crystalline property relationships of the symmetrical dimers was examined in order to explain the reasons for the non-liquid crystalline properties in the current chalcones.
\end{abstract}

Keywords: heterocycle, pyridine, chalcone, dimer, synthesis.

\section{Introduction}

Chalcone is a compound comprising two aromatic rings connected by an unsaturated $\alpha, \beta$-ketone, with various substituents on the two aromatic rings. Chalcone occurs naturally in most of the plants and is an intermediate precursor of flavonoids and isoflavonoids. ${ }^{1}$ It was reported to have comprehensive applications in the fields of biology and biochemistry ${ }^{2,3}$ as anti-tumor, ${ }^{4,5}$ antiinflammatory $^{6-8}$ and anti-malaria ${ }^{9}$ agent. In addition, it is also reported for its photochemical and photophysical properties, including being used as photo-alignment and photo-crosslinking unit in polymerization process, ${ }^{10}$ fluorescent dyes, light-emitting diodes (LEDs), etc. ${ }^{11}$

Liquid crystals with a chalcone central linkage are relatively rare. In the literature there are several reports of

\footnotetext{
${ }^{1}$ Faculty of Science, Universiti Tunku Abdul Rahman, Jln Universiti, Bandar Barat, 31900 Kampar, Perak, Malaysia

\ast@utar.edu.my; hast_utar@yahoo.com

(c) Lai, P.-M.; Ha, S.-T., 2022
}

mesomorphic compounds having chalcone linkage. However, many years ago Chudgar and Shah ${ }^{12}$ and Yeap et al. $^{13}$ reported homologous series containing esterchalcone linkages. Thaker and co-workers ${ }^{14}$ have also studied mesomorphic compounds containing Schiff basechalcone linkage. Ha and Low ${ }^{15}$ had studied the properties of chalcone with different terminal polar substituents ( $\mathrm{F}$, $\mathrm{Cl}, \mathrm{Br}$ and $\mathrm{NO}_{2}$ ). The previous studies were mainly on the aromatic-based chalcone and having calamitic (nondimeric) structure. In our attempt to incorporate heterocyclic ring into chalcone skeleton, we have recently synthesized the chalcone with heterocyclic pyridine-based liquid crystal, 4-[3-(pyridin-4-yl)prop-2-enoyl]phenyl 4alkyloxybenzoates. ${ }^{16}$ In this continuation work, our aim is to synthesize the dimers of heterocyclic pyridine-based chalcone. Here, we report three analogues of symmetrical dimers, $\alpha, \omega$-bis $\{3$-(pyridin-3-yl)-1-(phenyl-4-oxy)prop-2en-1-one\} alkanes (Fig. 1).

\section{Experimental}

\subsection{Materials and Methods}

All reagents used were purchased from commercial suppliers without further purification. Intermediate, 1-(4hydroxyphenyl)-3-(pyridin-3-yl)prop-2-en-1-one was prepared according to a previously reported method. ${ }^{15}$ The synthetic route for the title compounds is illustrated in Fig. 1. Compound purity was confirmed using TLC on silica gel 60 F254. Melting point determination was done using the Stuart SMP10 digital melting point apparatus and was recorded in ${ }^{\circ} \mathrm{C}$. Electron ionization mass spectrum was recorded by a Finnigan MAT95XL-T mass spectrometer operating at $70 \mathrm{eV}$ ionizing energy. FT-IR spectra were acquired on Perkin Elmer 2000-FTIR spectrophotometer in the frequency range of $4000-400 \mathrm{~cm}^{-1}$ with samples prepared as $\mathrm{KBr}$ pellets. NMR spectra were recorded in $\mathrm{CDCl}_{3}$ by utilizing JEOL $400 \mathrm{MHz}$ NMR Spectrometer with TMS as internal standard. The phase transition 
temperatures were measured by Mettler Toledo DSC 823 Differential Scanning Calorimeter (DSC) at the scanning rate of $10^{\circ} \mathrm{C} / \mathrm{min}$.

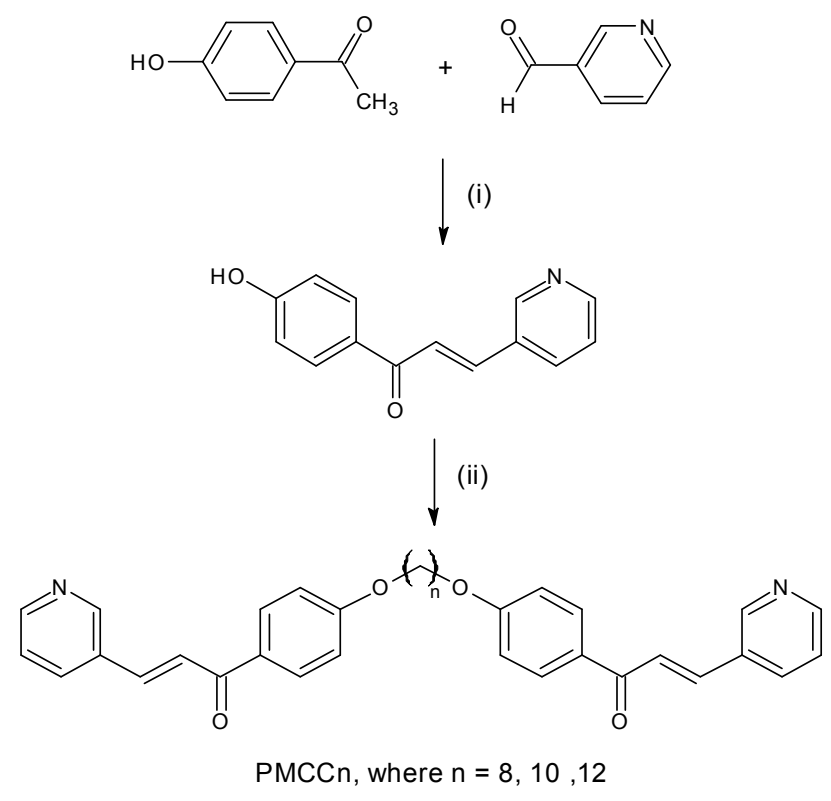

Fig. 1. Synthetic route towards formation of the title compounds. Reagents and conditions: (i) EtOH/ $\mathrm{H}_{2} \mathrm{O}(1: 1), \mathrm{KOH}$, stirred at r.t., $24 \mathrm{~h}$, neutralized with $2 \mathrm{M} \mathrm{HCl}$; (ii) Dibromoalkane $\left(\mathrm{C}_{\mathrm{n}} \mathrm{H}_{2 \mathrm{n}} \mathrm{Br}_{2}, n=8,10\right.$ and 12), $\mathrm{K}_{2} \mathrm{CO}_{3}, \mathrm{KI}$, acetone, reflux $24 \mathrm{~h}$

\subsection{Synthesis of $\alpha, \omega$-bis $\{3-($ pyridin-3-yl)- 1-(phenyl-4-oxy)prop-2-en-1-one $\}$ alkanes}

1-(4-Hydroxyphenyl)-3-(pyridin-4-yl)prop-2-en-1one $(2 \mathrm{mmol})$ and dibromoalkane $(1 \mathrm{mmol})$ were added into $30 \mathrm{~mL}$ of acetone. Then, the mixture was stirred and heated under reflux for $24 \mathrm{~h}$ in the presence of potassium carbonate and potassium iodide. Upon completion of the reaction, the mixture was then cooled to room temperature and followed by addition of distilled water $(80 \mathrm{~mL})$. The resulting precipitate was filtered and washed with water. The final products were recrystallized with ethanol until constant transition temperature was obtained. Melting points of the products are given as follow: PMCC8 $\left(168.2^{\circ} \mathrm{C}\right), \mathrm{PMCC} 10\left(157.2^{\circ} \mathrm{C}\right)$ and $\mathrm{PMCC} 12\left(153.0^{\circ} \mathrm{C}\right)$. Percentage yields of the products are listed as follow: PMCC8 (50\%), PMCC10 (56\%) and PMCC12 (60\%).

The IR and NMR $\left({ }^{1} \mathrm{H}\right.$ and $\left.{ }^{13} \mathrm{C}\right)$ data of the representative compound, $\mathrm{PMCC} 12$ are summarized as below.

IR $(\mathrm{KBr}) v_{\max } \mathrm{cm}^{-1}: 2937,2849$ (C-H aliphatic), $1659(\mathrm{C}=\mathrm{O}), 1637(\mathrm{C}=\mathrm{C}$ olefinic $), 1604,1474(\mathrm{C}=\mathrm{C}$ aromatic), $1256(\mathrm{C}-\mathrm{O}) ;{ }^{1} \mathrm{H} \mathrm{NMR}\left(400 \mathrm{MHz}, \mathrm{CDCl}_{3}\right.$, $\delta \mathrm{ppm}): 1.26-1.38\left\{\mathrm{~m}, 12 \mathrm{H}, 2 \mathrm{x}-\mathrm{O}\left(\mathrm{CH}_{2}\right)_{3}\left(\mathrm{CH}_{2}\right)_{3}\right\}, 1.46$ $\left\{\mathrm{p}, J=6.9 \mathrm{~Hz}, 4 \mathrm{H}, 2 \mathrm{x}-\mathrm{O}\left(\mathrm{CH}_{2}\right)\left(\mathrm{CH}_{2}\right)\left(\mathrm{C}_{2}\right)\right\}, 1.80\{\mathrm{p}$,
$\left.J=7.1 \mathrm{~Hz}, 4 \mathrm{H}, 2 \mathrm{x}-\mathrm{O}\left(\mathrm{CH}_{2}\right)\left(\mathrm{C}_{2}\right)\left(\mathrm{CH}_{2}\right)\right\}, 4.03$ (t, $\left.J=6.4 \mathrm{~Hz}, 4 \mathrm{H}, 2 \mathrm{x}-\mathrm{OCH}_{2}\right), 7.60(\mathrm{~d}, J=15.6 \mathrm{~Hz}, 1 \mathrm{H}$, olefinic-H), 7.76 (d, $J=16.0 \mathrm{~Hz}, 1 \mathrm{H}$, olefinic-H), 6.96 (d, $J=8.7 \mathrm{~Hz}, 4 \mathrm{H}, \mathrm{Ar}-\mathrm{H}), 8.02(\mathrm{~d}, J=8.0 \mathrm{~Hz}, 4 \mathrm{H}, \mathrm{Ar}-\mathrm{H})$, 7.34 (dd, $J=7.8 \mathrm{~Hz}, 4.6 \mathrm{~Hz}, 2 \mathrm{H}$, pyridine protons), 7.93 (dt, $J=7.8 \mathrm{~Hz}, 1.8 \mathrm{~Hz}, 2 \mathrm{H}$, pyridine protons), 8.60 (dd, $J=4.6 \mathrm{~Hz}, 1.8 \mathrm{~Hz}, 2 \mathrm{H}$, pyridine protons), 8.84 (d, $J=1.8 \mathrm{~Hz}, 2 \mathrm{H}$, pyridine protons); ${ }^{13} \mathrm{C}$ NMR $(100 \mathrm{MHz}$, $\mathrm{CDCl}_{3} \quad \delta$ ppm): 26.07, 29.18, 29.43, 29.63 for $\left\{-\mathrm{O}\left(\mathrm{CH}_{2}\right)\left(\mathrm{CH}_{2}\right)_{5}\right\}, 68.42$ for $\left(-\mathrm{OCH}_{2}\right), 114.50,123.87$, $130.45,131.02,134.72,149.90,150.94,163.44$ for aromatic and pyridine carbons, 123.82, 140.07 for olefinic carbons, $188.08(\mathrm{C}=\mathrm{O}$ keto $)$.

\section{Results and Discussion}

\subsection{FT-IR, ${ }^{1} \mathrm{H}$ NMR and ${ }^{13} \mathrm{C}$ NMR Spectra}

The heterocyclic chalcones were synthesized in two-steps reaction. First, the chalcone skeleton was obtained through base-catalyzed Claisen-Schmidt condensation method. Second, the formation of alkyl spacer was through Williamson etherification. These reactions are summarized in Fig. 1.

The chalcones were obtained as yellow powder. The chemical structures of the synthesized chalcones were confirmed using FTIR, ${ }^{1} \mathrm{H}$ NMR and ${ }^{13} \mathrm{C}$ NMR.

The FTIR spectrum of heterocyclic chalcone gave absorptions at 1659 and $1637 \mathrm{~cm}^{-1}$, corresponding to the $\mathrm{C}=\mathrm{O}$ and $\mathrm{C}=\mathrm{C}$ functional groups that are characteristic of the $\alpha, \beta$-unsaturated ketone moiety. Strong absorption bands emerged at 2937 and $2849 \mathrm{~cm}^{-1}$ confirmed the presence of aliphatic $\mathrm{C}-\mathrm{H}$ in alkyl chain. A sharp band at $1256 \mathrm{~cm}^{-1}$ can be ascribed to $\mathrm{C}-\mathrm{O}$ bonds of aromatic ether linking group. Absorption bands appeared at 1604 and $1474 \mathrm{~cm}^{-1}$ designate the aromatic $\mathrm{C}=\mathrm{C}$ linking group.

The ${ }^{1} \mathrm{H}$ NMR spectrum is shown in Fig. 2. The successful completion of a base-catalyzed ClaisenSchmidt condensation reaction in the synthesis of chalcone results in an enone system known as the $\alpha, \beta$ unsaturated ketone moiety. This was proven by the characteristic pair of doublets at $\delta=7.60$ and $7.76 \mathrm{ppm}$ due to vicinal coupling between $\mathrm{H}_{\alpha}$ and $\mathrm{H}_{\beta}$ with a coupling constant of $J=16 \mathrm{~Hz}$ pointing to a trans configuration. Triplet signal observed at $\delta=4.03 \mathrm{ppm}$, is attributed to the methylene protons attached to oxygen atom $\left(-\mathrm{OC}_{2}\right)$. The remaining methylene protons of the long chain appeared as multiplet, pentet and pentet signals at the respective chemicals shifts, $\delta=1.26-1.38,1.46$, and $1.80 \mathrm{ppm}$. Two distinct doublets detected at $\delta=6.96$ and 
$8.02 \mathrm{ppm}$ which each doublet integrated as two protons belong to the resonance of the para-substituted aromatic protons. Both signals are coupled with each other with a coupling constants of $8 \mathrm{~Hz}$. Signals attributed to the four pyridine protons were observed at $\delta=7.34,7.93,8.60$ and $8.84 \mathrm{ppm}$.

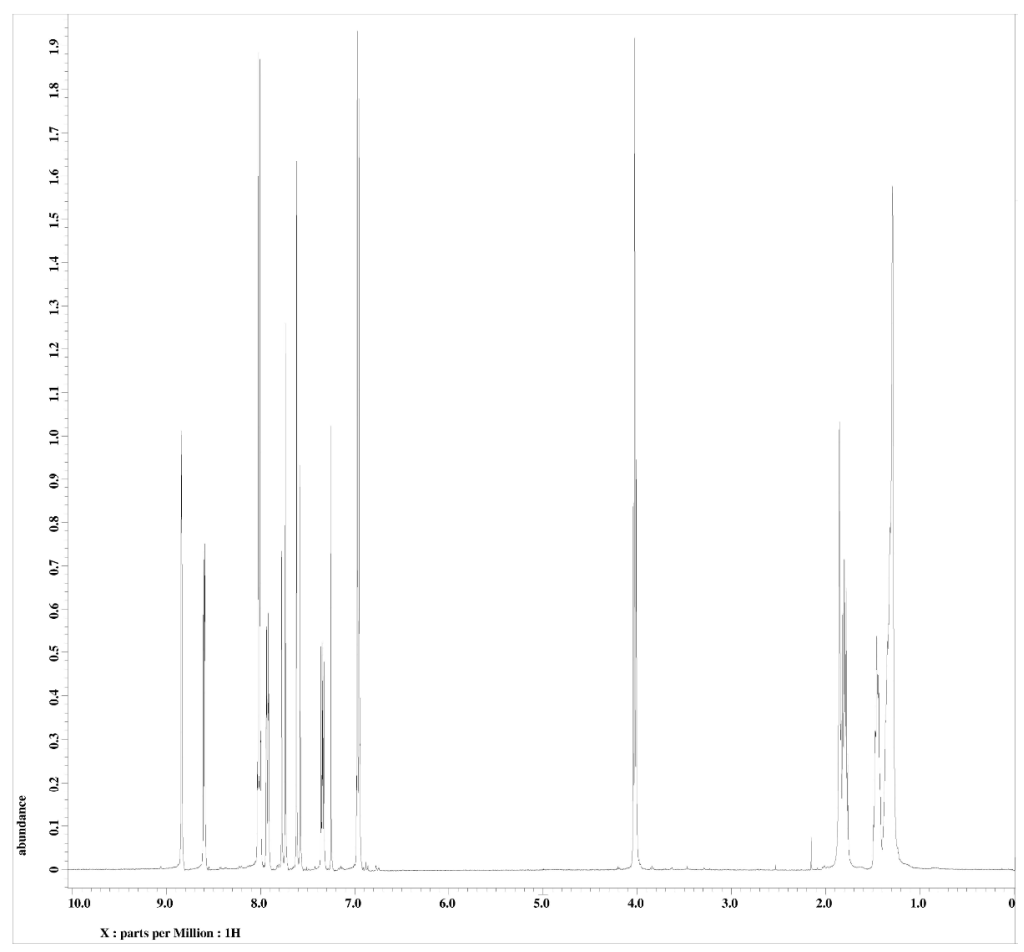

Fig. 2. ${ }^{1} \mathrm{H}$ NMR spectrum of symmetrical dimer, $\mathrm{PMCC} 12$

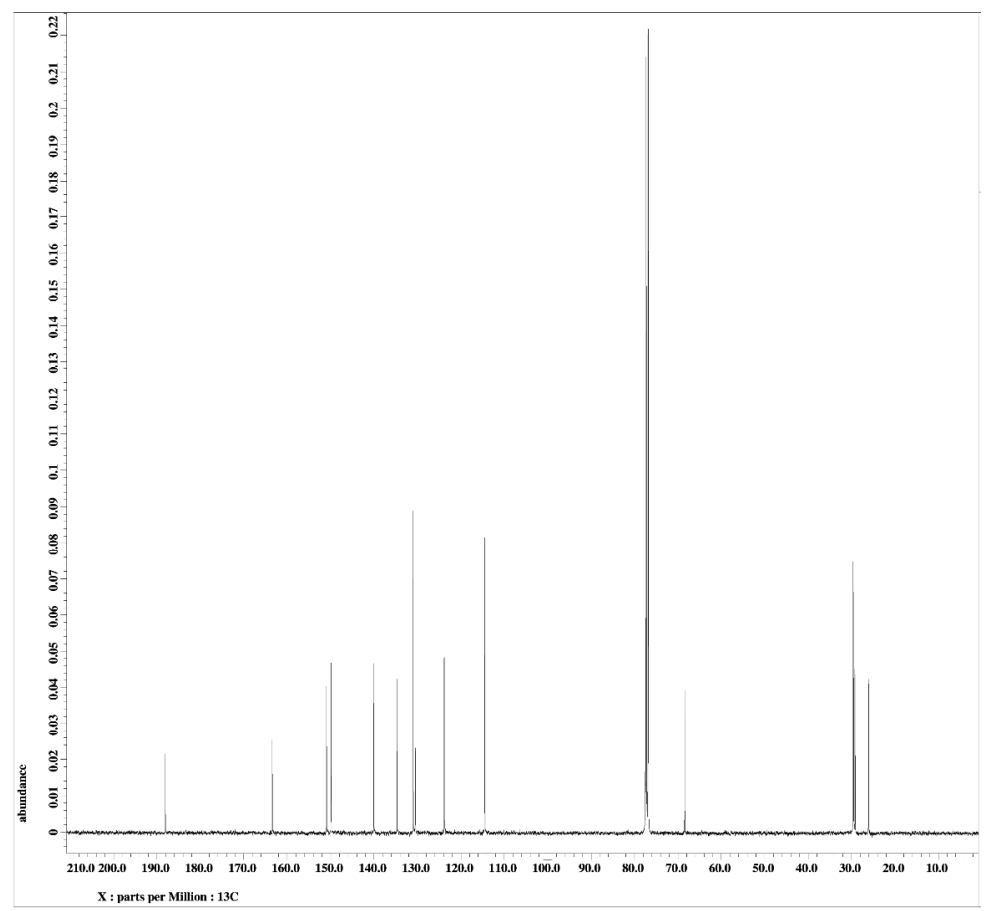

Fig. 3. ${ }^{13} \mathrm{C}$ NMR spectrum of symmetrical dimer, $\mathrm{PMCC} 12$ 
The ${ }^{13} \mathrm{C}$ NMR spectrum (Fig. 3) displayed a signal at the most downfield region of the spectrum, $\delta=188.08 \mathrm{ppm}$ corresponding to the presence of the carbonyl carbon of their $\alpha, \beta$-unsaturated ketone moiety. Olefinic carbons appeared at $\delta=123.82$ and $140.07 \mathrm{ppm}$ confirmed the presence of enone linking unit. A peak at $\delta=68.42 \mathrm{ppm}$ is attributed to the methylene carbons attached to oxygen atom $\left(-\mathrm{OC}_{2}-\right)$. The remaining methylene carbons were resonated at $\delta=26.07,29.18$, 29.43 , and $29.63 \mathrm{ppm} .{ }^{13} \mathrm{C}$ signals at $\delta=114.50$ $163.44 \mathrm{ppm}$ is assigned to aromatic and pyridine carbons.

\subsection{Phase Transition Behaviour of Chalcone Derivatives}

The thermal properties of new chalcones were studied using DSC. All homologous members were nonmesogenic compounds. The representative DSC thermogram of PMCC12 (Fig. 4) shows single endotherm and exotherm, respectively, during both heating and cooling cycles. This observation indicates direct melting of the crystal phase to the isotropic liquid phase (Cr-to-I) and vice versa (I-to-Cr). Therefore, no liquid crystal texture was observed during heating and cooling processes. Other members, PMMCn (where $\mathrm{n}=8,10$ ) showed the similar characteristics as those discussed for PMMC12.

\subsection{Effect of Alkyl Spacer Length on Transition Temperatures}

A further inspection on DSC data (Table 1) also illustrates the evolution of the Cr-to-I transition with the lengthening of spacers. This study revealed that the melting temperatures illustrate a gradual descending trend $\left(168.2{ }^{\circ} \mathrm{C} \rightarrow 157.2{ }^{\circ} \mathrm{C} \rightarrow 153.0{ }^{\circ} \mathrm{C}\right)$ with the increase in the length of alkyl spacer from $n=8$ to $n=12$. This phenomenon can be explained in terms of dilution of the core units which was influenced by the increase in the flexibility of spacer. ${ }^{17,18}$

Table 1. Transition temperatures, enthalpy changes and phase transitions of symmetrical dimers

\begin{tabular}{|c|c|c|}
\hline \multirow{2}{*}{ Compound } & \multicolumn{2}{|c|}{ Transition temperatures, ${ }^{\circ} \mathrm{C}\left(\Delta H, \mathrm{~kJ} \mathrm{~mol}^{-1}\right)$} \\
\cline { 2 - 3 } & Heating & Cooling \\
\hline PMCC8 & Cr 168.2(40.6) I & Cr 137.5 (38.7) I \\
\hline PMCC10 & Cr 157.2(57.4) I & Cr 135.3(57.2) I \\
\hline PMCC12 & Cr 153.0(50.2) I & Cr 140.3 (55.3) I \\
\hline
\end{tabular}

\subsection{Structure-Mesomorphic Property Relationships}

The mesomorphic behavior of organic compounds is sensitive to its molecular architecture; a slight alteration of molecular geometry brings about considerable change in its mesomorphic behaviour. ${ }^{19}$ Investigation of these factors by experimental or theoretical means should hopefully lead to a better understanding of structureproperty relationships on the synthesized compounds in liquid crystals.

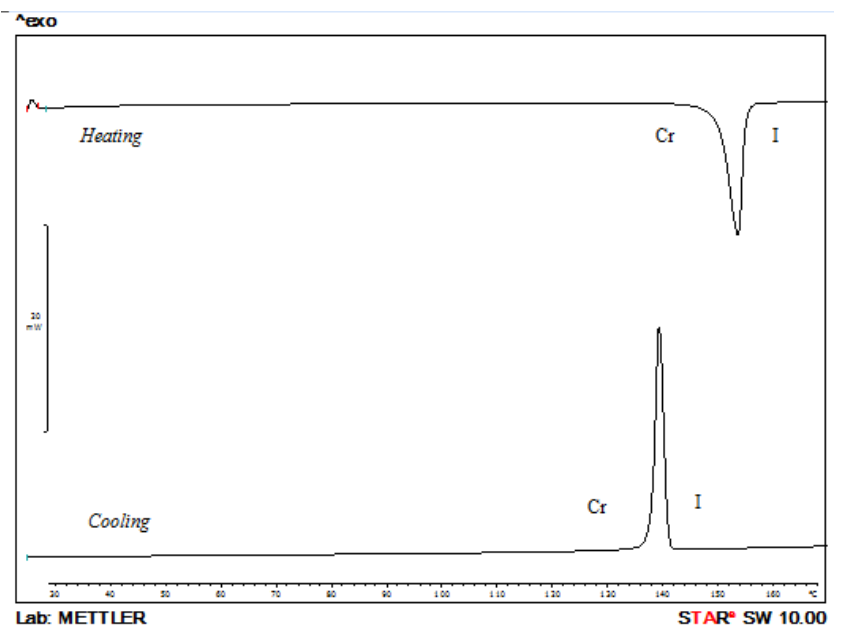

Fig. 4. DSC thermogram of symmetrical dimer, PMCC12

In order to relate the transitional properties with the chemical constitution of molecules, the present dimers are compared with the related liquid crystal dimers. The general molecular structure for these dimers labeled as $\mathrm{nBAm}^{20,21} 10 \mathrm{BABZ}^{18}$ and $\mathrm{nBABTP}^{22}$ and their phase sequences and transition temperatures are shown in Table 2.

Terminal groups showed strong influence on the mesomorphic properties of a molecule as presented in Table 2. It can be seen that the dimers with terminal alkyl chain, nBAm exhibited mesomorphic properties and dimers without terminal group, PMCCm are nonmesogens. Terminal chains bring flexibility into the molecule which is required to stabilize mesophases. ${ }^{23}$ Dimers with short terminal chain, 12BA6 and 12BA7 are nematogens and longer terminal chain promotes smectic phase in 12BA10.

Presence of pyridine ring in PMCCn is not the factor that prevents the current dimers from exhibiting mesophases. This can be evidenced from the case of $10 \mathrm{BABZ}$ and 10BATP wherein these compounds having heterocyclic benzothiazole and thiophene, respectively, are mesogens. However, it needs to complement with terminal polar chloro substituent like in the case of 10BABZ or having a longer molecular core through additional aromatic ring in 10BATP. Increasing the core length by inserting short unsaturated linkages (COO, ester) between phenyl and thiophene rings enhances the clearing temperature of 10BATP. 
Table 2. Comparison of mesomorphic behavior of PMCCn with structurally related dimers

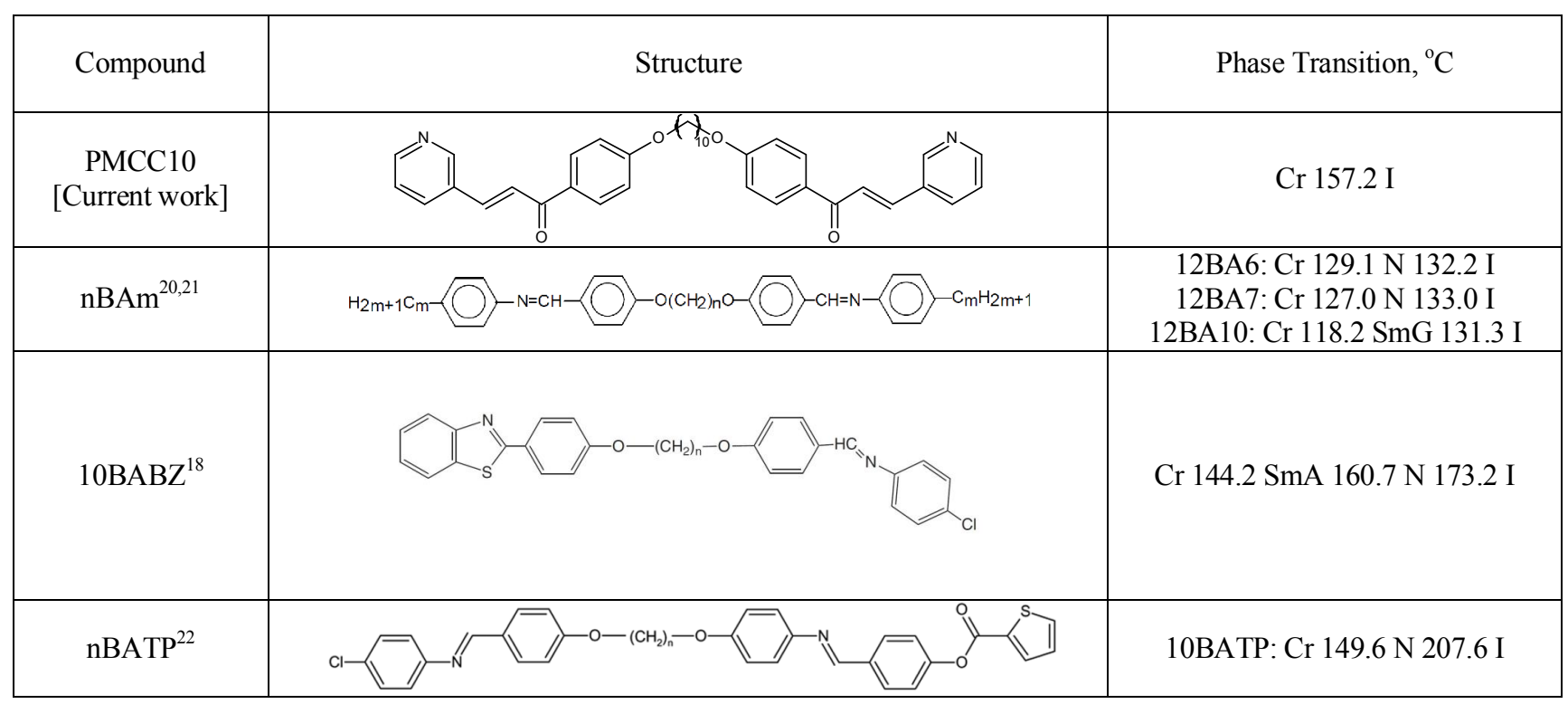

\section{Conclusions}

In this paper, we report the synthesis of new heterocyclic chalcones, $\alpha, \omega$-bis $\{3$-(pyridin-3-yl)-1(phenyl-4-oxy)prop-2-en-1-one\}alkanes. The spectral results matched with the molecular structures of the new chalcones. However, DSC analysis found that the chalcones did not exhibit liquid crystal properties. The influence of dimer spacer length, terminal chain and core rings on mesomorphic properties was discussed and compared with the reported dimer liquid crystals. The reason of the chalcone dimers for not exhibiting liquid crystal phase could be due the lack of polar group at the terminal position and lack of extra aromatic ring as the core system in a liquid crystal molecule. Therefore, the current dimers need to be modified in order to generate liquid crystal phase. These findings can serve as reference for future researches of heterocyclic pyridine chalconebased dimer liquid crystals. In addition, the presence of the pyridine group makes this system a suitable component (or intermediate) for building charge transferbased liquid crystals with an appropriate choice of acceptor molecules in future studies.

\section{Acknowledgements}

The authors would like to thank Universiti Tunku Abdul Rahman for the financial supports and research facilities.

\section{References}

[1] Achanta, G.; Modzelewska, A.; Feng, L.; Khan, S.R.; Huang P. A Boronic-Chalcone Derivative Exhibits Potent Anticancer Activity through Inhibition of the Proteasome. Mol. Pharmacol. 2005, 70, 426-433. https://doi.org/10.1124/mol.105.021311

[2] Bukhari, S.N.A.; Jasamai, M.; Jantan, I.; Ahmad, W. Review of Methods and Various Catalysts Used for Chalcone Synthesis. Mini Rev. Org. Chem. 2013, 10, 73-83.

https://doi.org/10.2174/1570193X11310010006

[3] Bukhari, S.; Jasamai, M.; Jantan, I. Synthesis and Biological Evaluation of Chalcone Derivatives (Mini Review). Mini Rev. Med. Chem. 2012, 12, 1394-1403.

https://doi.org/10.2174/138955712804586648

[4] Saydam, G.; Aydin, H.H.; Şahin, F.; Kucukoglu, O.; Erciyas, E.; Terzioglu, E.; Buyukkeçeci, F.; Omay, S.B. Cytotoxic and Inhibitory Effects of 4,4'-Dihydroxy Chalcone (RVC-588) on Proliferation of Human Leukemic HL-60 Cells. Leukemia Res. 2003, 27, 57-64. https://doi.org/10.1016/S0145-2126(02)00058-9

[5] Mishra, L.; Itokawa, H.; Bastow, K.F.; Tachibana, Y.; Nakanishi, Y.; Kilgore, N.; Lee, K.-H.; Sinha, R. Anti-HIV and Cytotoxic Activities of $\mathrm{Ru}(\mathrm{II}) / \mathrm{Ru}(\mathrm{III})$ Polypyridyl Complexes Containing 2,6(2'-Benzimidazolyl)-pyridine/chalcone as Co-Ligand. Bioorg. Med. Chem. 2001, 9, 1667-1671. https://doi.org/10.1016/S09680896(01)00074-8

[6] Ko, H.-H.; Tsao, L.-T.; Yu, K.-L.; Liu, C.-T.; Wang, J.-P.; Lin, C.-N. Structure-Activity Relationship Studies on Chalcone Derivatives: The Potent Inhibition of Chemical Mediators Release. Bioorg. Med. Chem. 2003, 11, 105-111.

https://doi.org/10.1016/S0968-0896(02)00312-7

[7] Tuchinda, P.; Reutrakul, V.; Claeson, P.; Pongprayoon, U.; Sematong, T.; Santisuk, T.; Taylor, W.C. Anti-Inflammatory Cyclohexenyl Chalcone Derivatives in Boesenbergia Pandurate. Phytochem. 2002, 59, 169-173. https://doi.org/10.1016/S00319422(01)00451-4

[8] Bukhari, S.N.A.; Jantan, I.B.; Jasamai, M.; Ahmad, W.; Amjad, M.W.B. Synthesis and Biological Evaluation of Curcumin Analogues. Mini Rev. Med. Chem. 2013, 13, 501-513. https://doi.org/10.3923/jms.2013.501.513

[9] Domínguez, J.N.; León, C.; Rodrigues, J.; de Domínguez, N.G.; Gut, J.; Rosenthal, P.J. Synthesis and Evaluation of New Antimalarial Phenylurenyl Chalcone Derivatives. J. Med. Chem. 2005, 48, 3654-3658. https://doi.org/10.1021/jm058208o 
[10] Shin, D.-M.; Song, D.-M.; Jung, K.-H.; Moon, J.-H. Photochemical Transformation of Chalcone Derivatives. J. Photosci. 2001, 8, 9-12.

[11] Suwunwong, T. Syntheses and Fluorescent Properties of Chalcone Derivatives and Heteroarylchalcones. MSc thesis, Prince of Songkla University, Thailand, 2010.

[12] Chudgar, N.K.; Shah, S.N. New Fluorescent Mesogens with a Chalcone Central Linkage. Liq. Cryst. 1989, 4, 661-668.

https://doi.org/10.1080/02678298908033201

[13] Yeap, G.-Y.; Susanti, I.; Teoh, B.-S.; Mahmood, W.A.K.

Harrison, W.T.A. Synthesis and Phase Transition in New Chalcone Derivatives: Crystal Structure of 1-Phenyl-3-(4'-

undecylcarbonyloxyphenyl)-2-propen-1-one. Mol. Cryst. Liq. Cryst. 2005, 442, 133-146. https://doi.org/10.1080/154214090964753

[14] Thaker, B.T.; Patel, P.H.; Vansadiya, A.D.; Kanojiya, J.D. Substitution Effects on the Liquid Crystalline Properties of Thermotropic Liquid Crystals Containing Schiff Base Chalcone Linkages. Mol. Cryst. Liq. Cryst. 2009, 515, 135-147.

https://doi.org/10.1080/15421400903291533

[15] Ha, S.T.; Low, Y.W. Synthesis and Phase Transition

Behaviours of New Chalcone Derivatives. J. Chem. 2013, 2013. https://doi.org/10.1155/2013/943723

[16] Lim, Y.-W.C.; Ha, S.-T.; Yeap, G.-Y.; Sastry, S.S. Synthesis and Mesomorphic Properties of New Heterocyclic Liquid Crystals with Central Ester-Chalcone Linkages. J. Taibah Univ. Sci. 2017, 11, 133-140. https://doi.org/10.1016/j.jtusci.2015.12.004

[17] Collings, P.J.; Hilger, A. Liquid Crystal: Nature's Delicate Phase of Matter. IOP Publishing Ltd.: Bristol, 1990.

[18] Yeap, G.-Y.; Al-Taifi, E.A.; Ong, C.-H.; Mahmood, W.A.K.; Takeuchi, D.; Ito, M.M. Synthesis and Phase Transition Studies on Non-Symmetric Liquid Crystal Dimers: N-(4-(n-(4-(Benzothiazol2-yl)phenoxy)alkyloxy)-benzylidene)-4-chloroanilines. Phase Trans. 2012, 85, 483-496. https://doi.org/10.1080/01411594.2011.624278 [19] Prajapati, A.K.; Bonde, N.L.; Patel, H.N. Mesogenic Schiff's Base Ester with Chloroethyl Tail. Phase Trans. 2005, 78, 507-513. https://doi.org/10.1080/01411590500188876

[20] Parameswara Rao Alapati; Bhuyan, D.; Madhavi Latha, D.; Pardhasaradhi, P.; Pisipati, V.G.K.M.; Datta Prasad, P.V.; Singh, K.N. Study of Molecular Polarizabilities and Orientational Order Parameter in the Nematic Phase of 6.O12O.6 and 7.O12O.7. World
J. Condens. Matt. Phys. 2011, 1, 167-174.

https://doi.org/10.4236/wjcmp.2011.14025

[21] Gogoi, B.; Alapati, P.R.; Verma, A.L. Phase Transition Studies in Mesogenic Dimers. Cryst. Res. Technol. 2002, 37, 1331-1337. https://doi.org/10.1002/crat.200290010

[22] Yeap, G.-Y.; Hng, T.-C.; Takeuchi, D.; Osakada, K.; Mahmood, W.A.K.; Ito, M.M. Non-Symmetric Liquid Crystal Dimers: High Thermal Stability in Nematic Phase Enhanced by Thiophene-2Carboxylate Moiety. Mol. Cryst. Liq. Cryst. 2009, 506, 134-149. https://doi.org/10.1080/15421400902987248

[23] Vill, V. Liquid Crystals, Molecular Design of: Calamitics. In Encyclopedia of Materials: Science and Technology; Buschow, K.H.J.; Cahn, R.W.; Flemings, M.C.; Ilschner, B.; Kramer, E.J.; Mahajan, S.; Veyssière, P., Eds.; Elsevier Science Ltd, 2001; pp 4545-4550. https://doi.org/10.1016/B0-08-043152-6/00796-8

Received: October 04, 2019 / Revised: November 20, 2019 / Accepted: February 27, 2020

\section{СИНТЕЗ ГЕТЕРОЦИКЛІЧНИХ ХАЛКОНІВ ДИМЕРНОЇ СТРУКТУРИ НА ОСНОВІ ПІРИДИНУ}

Анотація. Синтезовано три нові гетероциклічні халкони, щзо містять піридиновий фрагмент. За допомогою ІЧспектроскопії, ${ }^{1}$ НЯМР та ${ }^{13}$ СЯМР визначено їх хімічну структуру, і встановлено, що вони відносяться до сполук $i_{3}$ загальною назвою $\alpha, \omega-б і с\{3-($ піридин-3-іл)-1-(феніл-4-окси)проп2-ен-1-он\}алкани. Халкони - ие димери, щуо мають симетричну структуру, $i$ відрізняються довжсиною алкільного проміжку $\left(C_{n} H_{2 n}\right.$, де $n=8,10$ або 12). Для визначення фазових переходів синтезованих сполук застосовано метод диференціальноі скануючої калориметрії (DSC). Термограми DSC відображають пряму ізотропізачію та перекристалізацію під час прочесів нагрівання та охолодження відповідно. Кристалічна фаза перетворюеться в ізотропну фазу, не виявляючи жодної мезофази. Вивчено вплив структурно-рідких кристалічних властивостей симетричних димерів, щоб пояснити причини нерідких кристалічних властивостей у діючих халконах.

Ключові слова: гетерочикл, піридин, халкон, димер, синтез. 